\title{
HOUSEHOLD ENERGY USE AND EMISSION
}

\author{
MOMADE IBRAIMO ${ }^{1,2}$, JAMES ROBINSON $^{3}$ \& HAROLD J. ANNEGARN ${ }^{2,3}$ \\ ${ }^{1}$ Department of Physics, Eduardo Mondlane University, Mozambique \\ ${ }^{2}$ Department of Geography, Environmental Management and Energy Studies, \\ University of Johannesburg, South Africa \\ ${ }^{3}$ SeTAR Centre, University of Johannesburg, South Africa
}

\begin{abstract}
Technological solutions for energy-efficient domestic use cannot be imposed without considering social and customary conditions, such as traditional practices of energy use in target communities. In order to establish an empirical baseline of rural energy use in an essentially subsistence village in northern Mozambique, we conducted a household survey to understanding what the cultural needs are, as well as an Uncontrolled Cooking Test (UCT) and aerosol measurements to evaluate the performance of cooking systems in use. The survey considered 146 scattered households, of which $92 \%$ are using firewood as their first choice for cooking, using a 3-stone fireplace, without extinguishing the fire or reusing char after completion of cooking tasks. The UCT results show that each household, average size 4.3 people, consumes $204 \mathrm{MJ}$ of fuelwood energy per day when cooking for 4 to 6 hours, divided into morning, midday and evening sessions. During cooking practices within indoor kitchens, women and children are exposed on average to $9800 \mu \mathrm{g} / \mathrm{m}^{3}$ per hour of wood-burning particulate matter. By using the methods stated above it is possible to establish a baseline of rural energy use and cooking system performance. Smoke from wood-burning 3-stone fireplaces is shown to be well above acceptable health standards. However, the dense smoke plays an important role in food conservation. Any proposed energy intervention should address the underlying cultural imperatives, the fuel options available and the preferred technologies.

Keywords: fuelwood, rural energy, indoor pollution, stove emissions, improved stoves, particulate matter.
\end{abstract}

\section{INTRODUCTION}

The use of biomass fuels for cooking is a major cause of health problems in developing countries due to indoor air pollution [1], [2]. High levels of poverty, environmental degradation and low income levels are common features in rural southern African countries (e.g. Mozambique). Rural households often rely on readily available biomass for cooking and space heating using inefficient stoves and fireplaces [1], [3]. As a result, forests are further depleted, with the daily exposure to significant levels of particulate and gaseous emissions negatively impacting on human health.

The domestic collection and use of biomass in many developing countries is a continued area of interest for researchers, policy makers and businesses alike. In Mozambique, where biomass accounts for over $80 \%$ of consumed energy [4] and $71 \%$ of the population lives in rural areas [1], there is the need to better characterize the energy baseline of rural villages in order to design and implement more effective technologies and policies.

Each household can vary their biomass options, skewed towards personal preferences at any given time - consuming a range of fuels along the energy ladder [3], [5]. Technologies to achieve recommended efficiency and emissions standards cannot be imposed without considering social and customary conditions, such as traditional practices of energy use and the impacts of energy efficiency improvements and cooking fuels substitution in target communities.

This study is closely related to the Volkswagen Foundation funded 'Modelling Bioenergy in Rural Southern Africa (BIOMODELS)'. Included in the BIOMODELS project aims were 
an understanding of the energy requirements and fuel choices by the rural population, and to establish the obstacles and opportunities for the use of fuel-efficient technologies by communities dependent on biomass energy. That particular programme, which includes the Universities of Johannesburg and Eduardo Mondlane as participants together with the universities of Stuttgart and Berlin (in Germany), Zambia, Cape Town and Witwatersrand was ran from 2006 to 2010 .

Using the main energy-related findings from BIOMODELS study, a research programme was devised and in May 2010 a team of researchers from the University of Johannesburg and Eduardo Mondlane University returned to the village to conduct a performance assessment of the most commonly used cooking systems. For Mozambique, as is the case for much of Southern Africa, this is the 3-stone fire burning locally collected firewood. Although the assessment of a particular cooking system can take place in either the laboratory or in-situ in a household, the nature of the 3-stone fire means that user behaviour (i.e. lighting and tending of the fire) can have a significant impact upon performance [6]. Therefore, the method adopted for this study is a revised in-situ testing protocol based on the Controlled Cooking Test [7] but that assesses the task-based performance of the system when cooking any meal and operated as per local conditions and practice.

The aims of the research are to: measure baseline energy access situation and cooking system performance of a typical rural subsistence village in northern Mozambique.

\section{METHODOLOGY}

\subsection{Study area}

In accordance with the BIOMODELS project objectives, the researchers have to choose their study areas in accordance with the following characteristics:

a) Subsistence village: economic footprint should be as close to the village as possible;

b) Measure of isolation: remote village;

c) Access to electricity: grid access;

d) Type of biomass mainly for energy purposes: main local domestic biomass use is wood;

e) Modern biofuel uses (biogas plant): not pilot;

f) Traditional biofuel uses: firewood and charcoal;

g) National context: village should be representative.

This study was conducted in Muculuone village, a typical remote village close to Nacala Corridor, located in Muecate District, north-eastern Nampula province, Mozambique (Fig. 1).

In 1997 the population of Muculuone was 16,500 people [4]. Subsistence agriculture and fuelwood sales are the main economic activities. The firewood and charcoal are sold in periurban areas surrounding the large city of Nampula.

\subsection{Survey methodology}

A household questionnaire survey was conducted, the questionnaire dealt with rural household energy utilisation and attitudes to various sources of energy: household structure, energy use and appliances; sourcing, supply and purchase of biofuel (firewood and charcoal), electricity and other energy sources. The questionnaires were administered with the assistance of local students of Pedagogic University, from the 21st to 26th September 2009. 


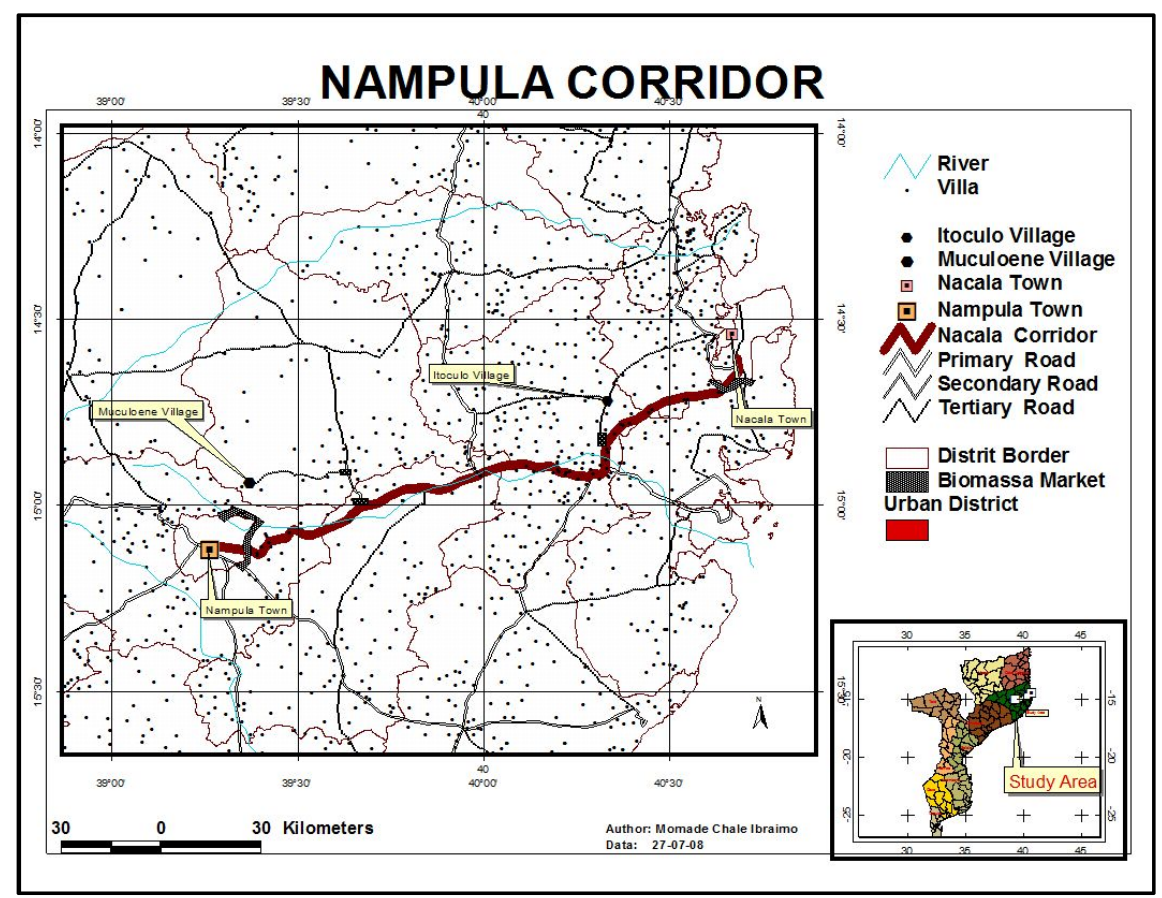

Figure 1: Study area in Nacala corridor, northern Mozambique. (Source: DINAGECA, 1995.)

From 3951 households, the survey considered 146 scattered households. The community questionnaire was work shopped in January 2008 to the Muculuone community leaders and groups about agriculture and forest services, economic activity, the charcoal production association and agricultural association.

A letter of informed consent to engage the community was negotiated with the Headman and duly authorised, in compliance with the ethics requirements and practice, then current, of the Eduardo Mondlane University and the Mozambique government.

\subsection{Uncontrolled Cooking Test (UCT) and aerosol measurements}

The UCT part of the study was conducted in May 2010, covering 24 households which represent $17 \%$ of the field survey households. Testing was limited to the 3 -stone fire during the dry season and prior to any rains. A total of 28 UCTs were conducted over a four-day period on a variety of meals in 24 households, with one household being tested three times, and three households being tested twice.

Following the methodology of the UCT [7], [8], the meal was not constrained and the cook was free to prepare what they wanted, how they wanted, with the only measurements being that of the firewood used and the final mass of food cooked as part of an actual household meal (Fig. 2). Equipment used for testing includes 2 different mass balances (an electronic for food: $\pm 1 \mathrm{~g}$ resolution; small field mass balance for fuel sampling), stopwatch, hot wood/char handling equipment, digital camera, and some sealable plastic food bags. 


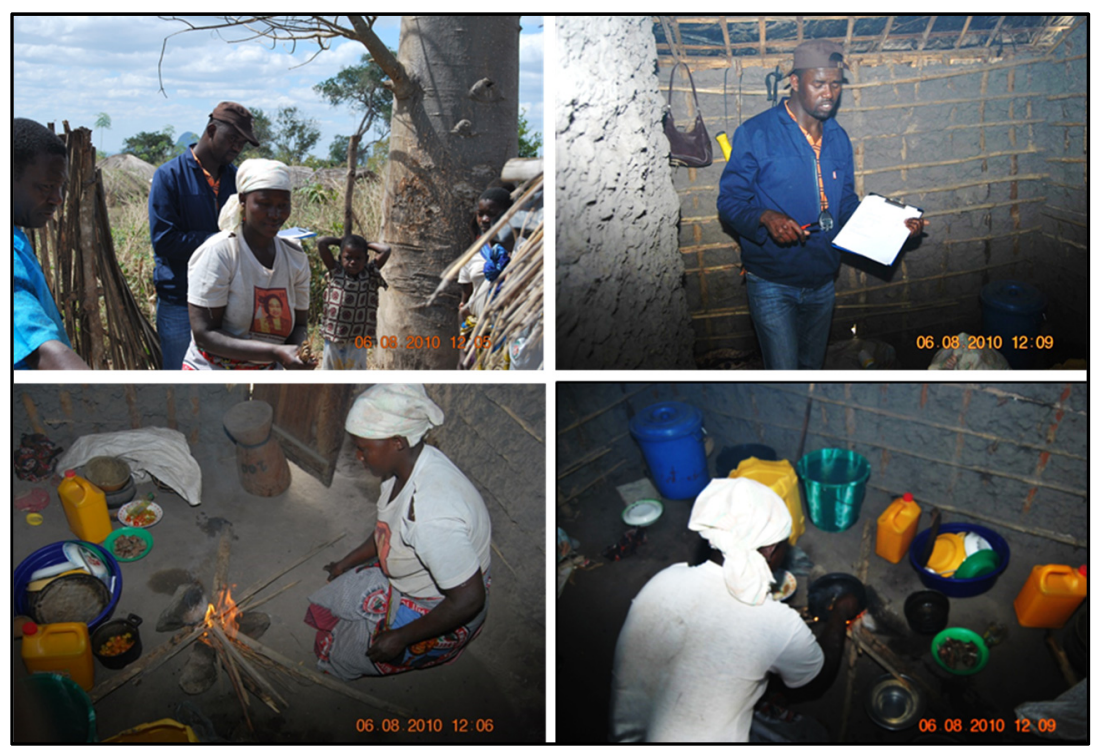

Figure 2: Uncontrolled Cooking Test in progress in inside a rural kitchen.

Aerosols were measured using a TSI DustTrak ${ }^{\mathrm{TM}}$ Aerosol Monitor Model 8520. This instrument reports mass concentrations of dust, smoke, mist and fumes in real time based on laser scattering, and stores the information in a built-in data logger. The DustTrak was set to record the PM2.5 aerosol fraction. The inlet of the instrument was placed $\sim 2 \mathrm{~m}$ from the smoke source, at $1 \mathrm{~m}$ above floor level. Readings were recorded at $60 \mathrm{~s}$ intervals over the cooking cycles, each lasting about two hours. Aerosol measurements were made simultaneously with the UCTs.

\section{RESULTS AND DISCUSSIONS}

\subsection{Survey results}

The majority of Muculuone population lives in thatched houses, without any windows. Some $79 \%$ of the households have an indoor kitchen, which is located inside the house. Smoke from cooking practices is used in food conservation (fumigating or smoking of grain, vegetables, cassava and meat) (Fig. 3).

The household survey shows the average comprises 4.3 members. The majority of the household comprise parents and their children. The survey shows that $54 \%$ of the respondents have been to school; $14 \%$ completed primary school and 3\% have completed secondary school. The village household head are not educated.

The village of Muculuone is a poor rural village; there is lack of job opportunities [1], [4]. The survey indicated that $51 \%$ of village people work in the fields, $23 \%$ is employed in the formal job, while $6 \%$ work as casual labourers. The unemployed comprise students, pensioners and the disabled. The main income source is from selling agriculture product and charcoal. A total of $59 \%$ of the households cannot generate enough income for standard living [1]. Table 1 shows some socio-economic indicators from the village survey. 


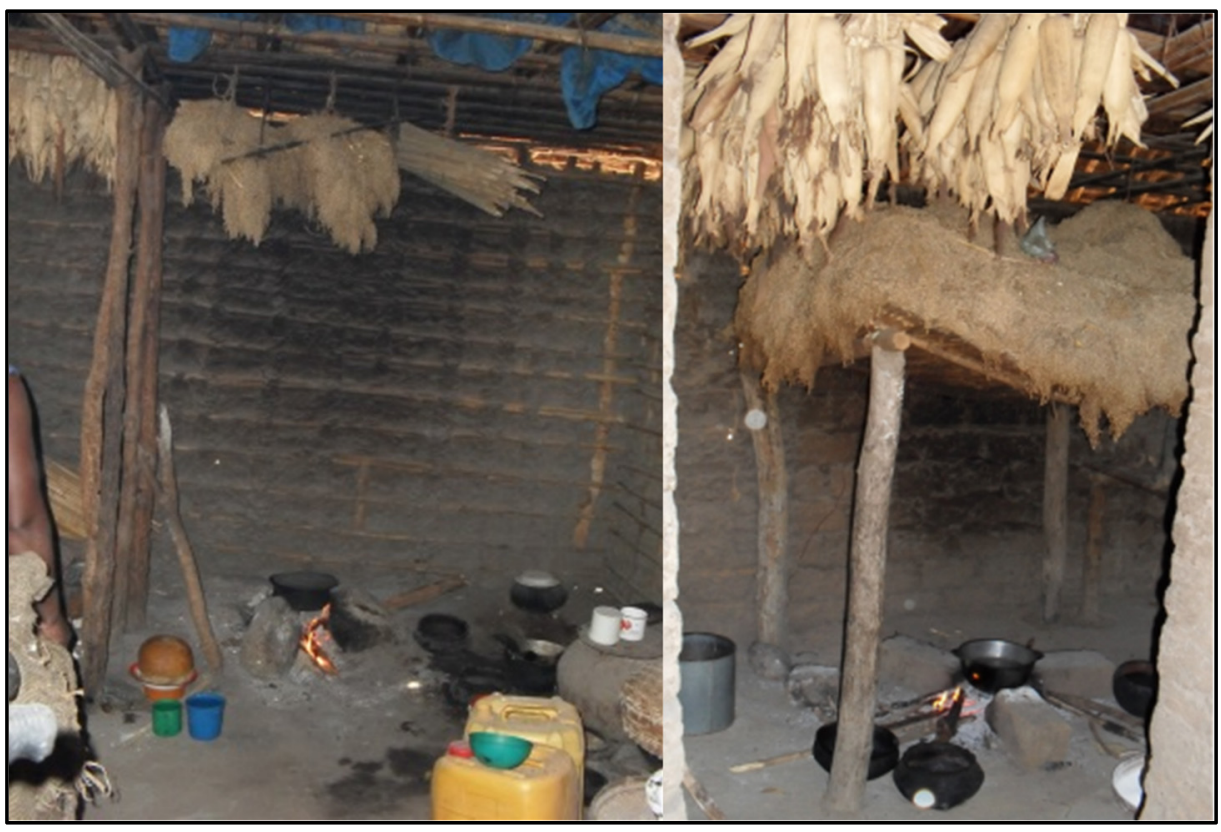

Figure 3: Typical indoor household kitchens, showing corn being dried and fumigated above the fireplace.

Table 1: 2008 socio-economic indicators of Muculuone.

\begin{tabular}{|ll|}
\hline Indicatory & Magnitude \\
\hline Main income source & $\begin{array}{l}\text { From employment (full time or part time) } \\
\text { and selling agricultural produce }\end{array}$ \\
\hline Income frequency & Monthly and infrequent \\
\hline Main income & $\begin{array}{l}15,037 \mathrm{MTn}^{\#} \text { per year, about USD500 per } \\
\text { year }\end{array}$ \\
\hline Per capita income & $\begin{array}{l}3537 \mathrm{MTn} \text { per year, about USD118 per } \\
\text { year }\end{array}$ \\
\hline Per capita expenditure & $\begin{array}{l}2252 \mathrm{MTn} \text { per year, about USD75 per } \\
\text { year }\end{array}$ \\
\hline "MTn: Meticais da Nova Familia - Mozambique currency.
\end{tabular}

MTn: Meticais da Nova Familia - Mozambique currency.

A total of $92 \%$ of households use firewood as first choice for cooking and space heating, while the remaining $8 \%$ use charcoal as first choice for cooking. For lighting, the main sources are paraffin and batteries (for flashlights). It is estimated that $51 \%$ of households are illuminated with paraffin, $30 \%$ with batteries and the remaining with firewood or candles (Fig. 4). 


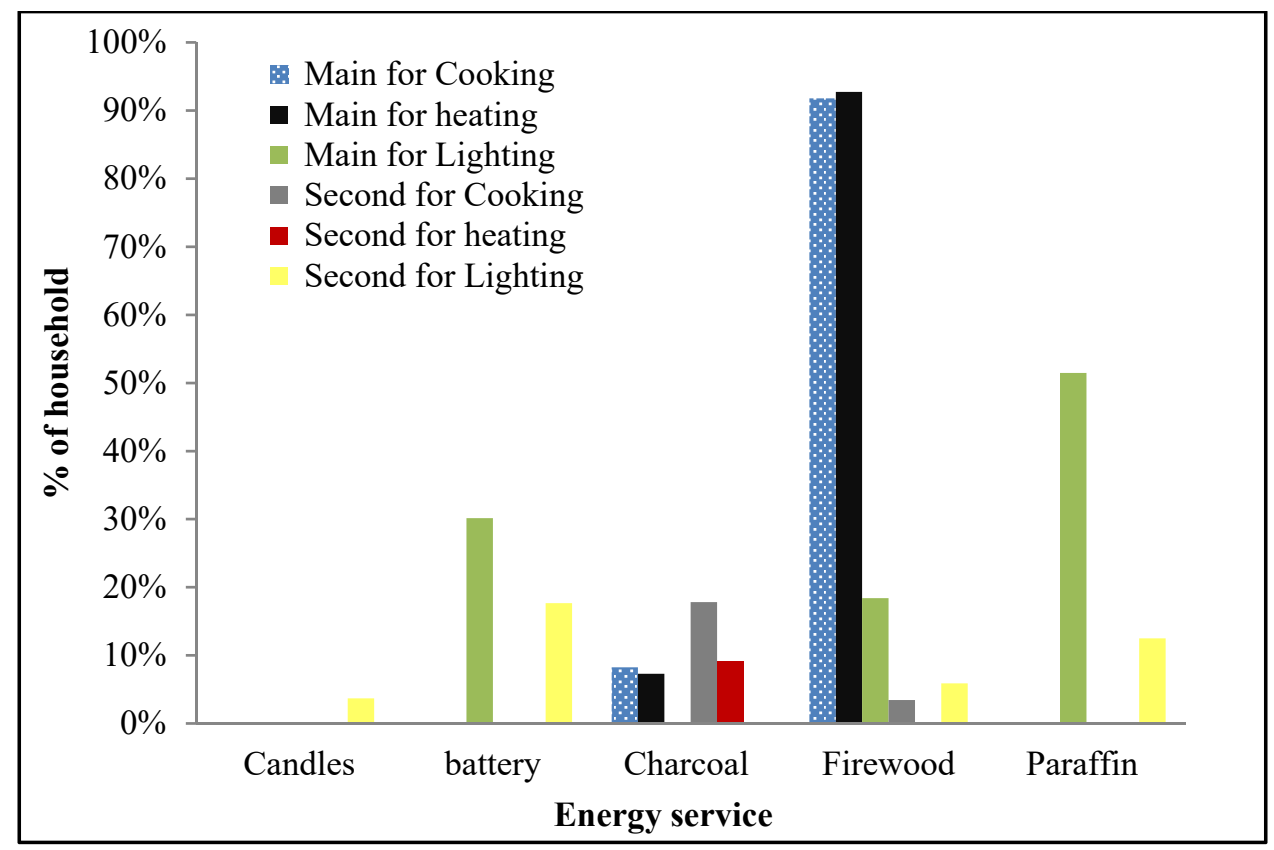

Figure 4: Household energy use patterns. The main source for cooking and space heating is firewood; for lighting, the main sources are paraffin and battery.

From the survey, it was found that each household collects $\sim 16 \mathrm{~kg}$ of firewood per day and spends $\sim 80$ min collecting firewood. In $60 \%$ of the households it is women who collect firewood.

The study indicates the preferred fuelwood species for cooking and space heating using the 3-stone fire place are Mpacala (Julbernardia globiflora) and Mukoi (Uapaca nitida) (Fig. 5). Fig. 6 shows the main factors influencing the household choice of 3-stone fireplaces for cooking.

\subsection{UCT results}

The UCT results show that each household consumes $204 \mathrm{MJ}$ of fuelwood energy per day when cooking for 4 to 6 hours, divided into morning, midday and evening sessions. The used wood had an average moisture content of $13.1 \pm 4.6 \%$ and a calorific value of $16.7 \mathrm{MJ} \mathrm{kg}^{-1}$.

The Specific Fuel Consumption (SFC) ranged widely between 7 and $17 \mathrm{MJ}$ of fuel per $\mathrm{kg}$ of food cooked, with the mode (highest frequencies at 14 and $15 \mathrm{MJ}$ per $\mathrm{kg}$ food cooked (Fig. 7).

During the UCT, it was observed that all households disposed any post-fire char rather than reusing it. The average of SFC in this study is presented in condition without char, which is $12 \pm 3 \mathrm{MJ}$ fuel per $\mathrm{kg}$ food cooked; $77 \%$ households cooked using two pots sequentially cooking different type of food; however, this did not influence the SFC. 


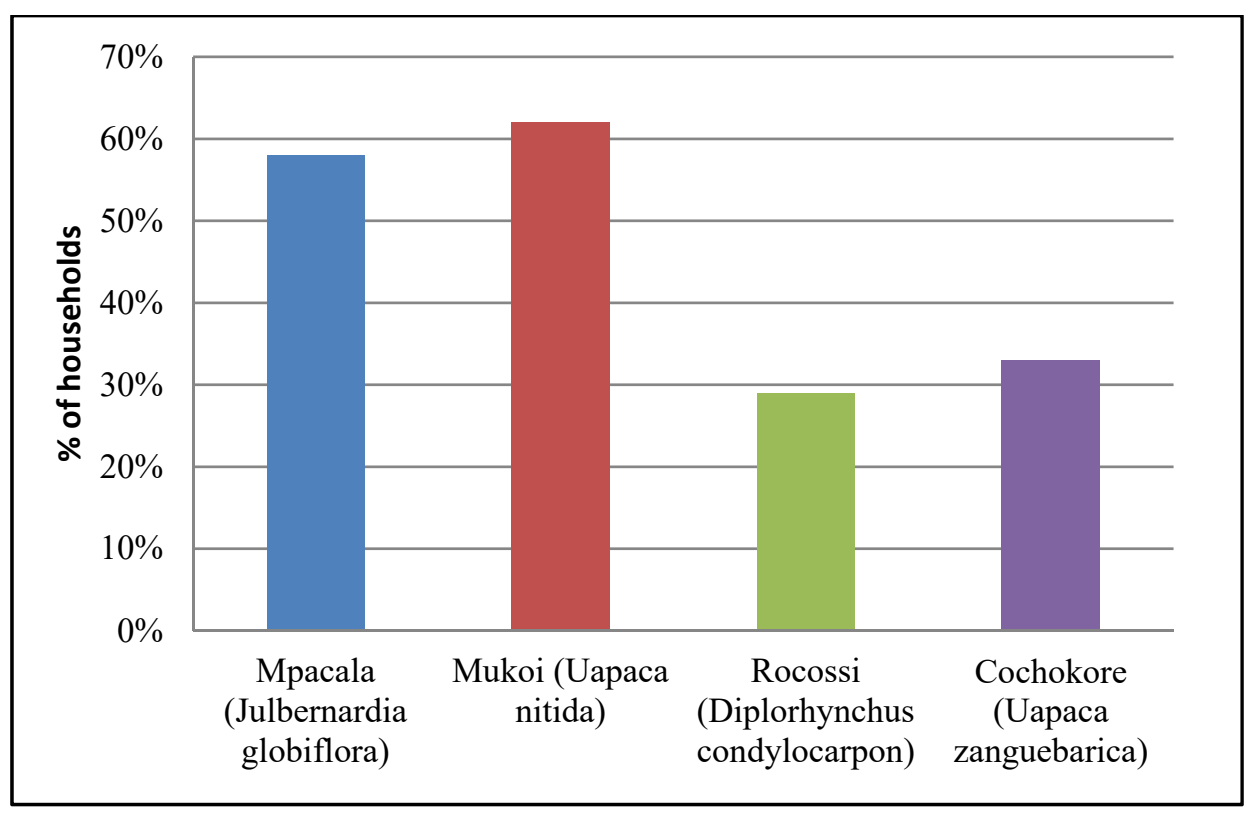

Figure 5: $\quad$ Species of tree most used by the households. Mpacala (Julbernardia globiflora) and Mukoi (Uapaca nitida) are the tree species mainly used by the village households.

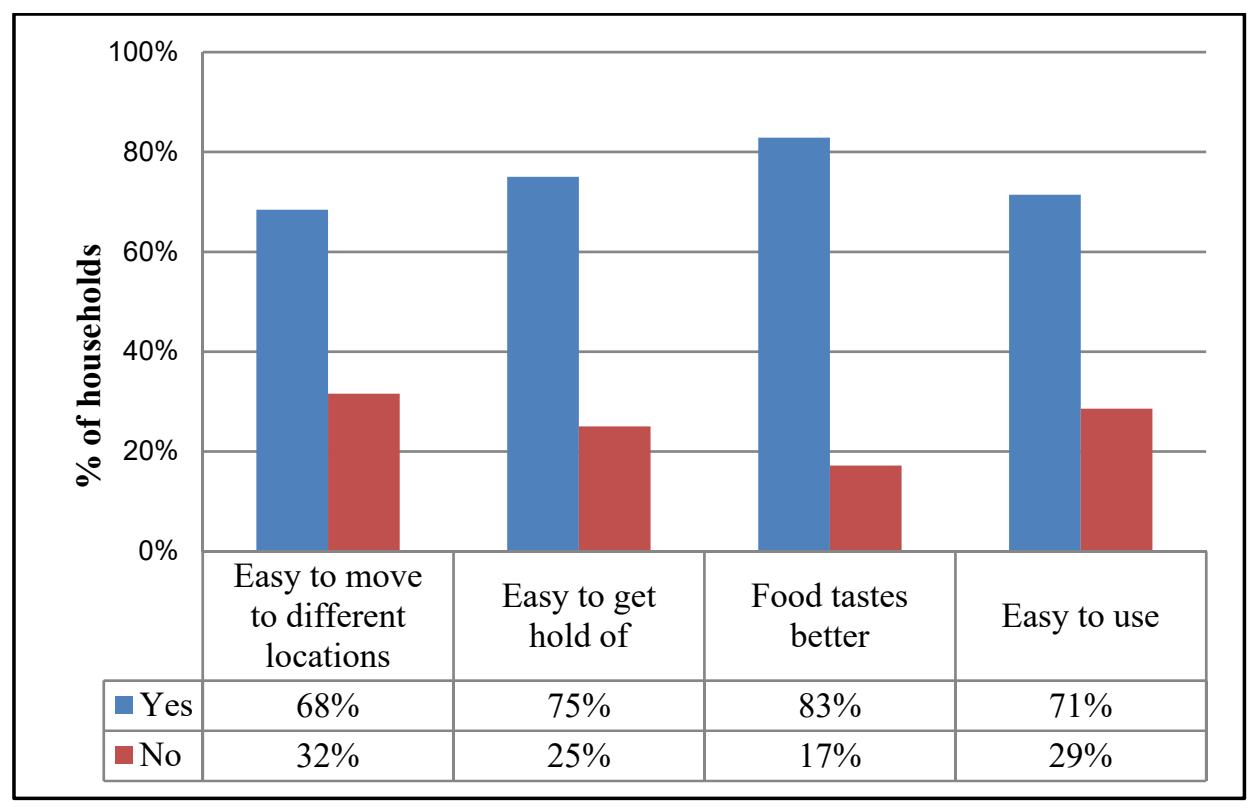

Figure 6: Factors influencing the household choice of own 3-stone fireplaces. 


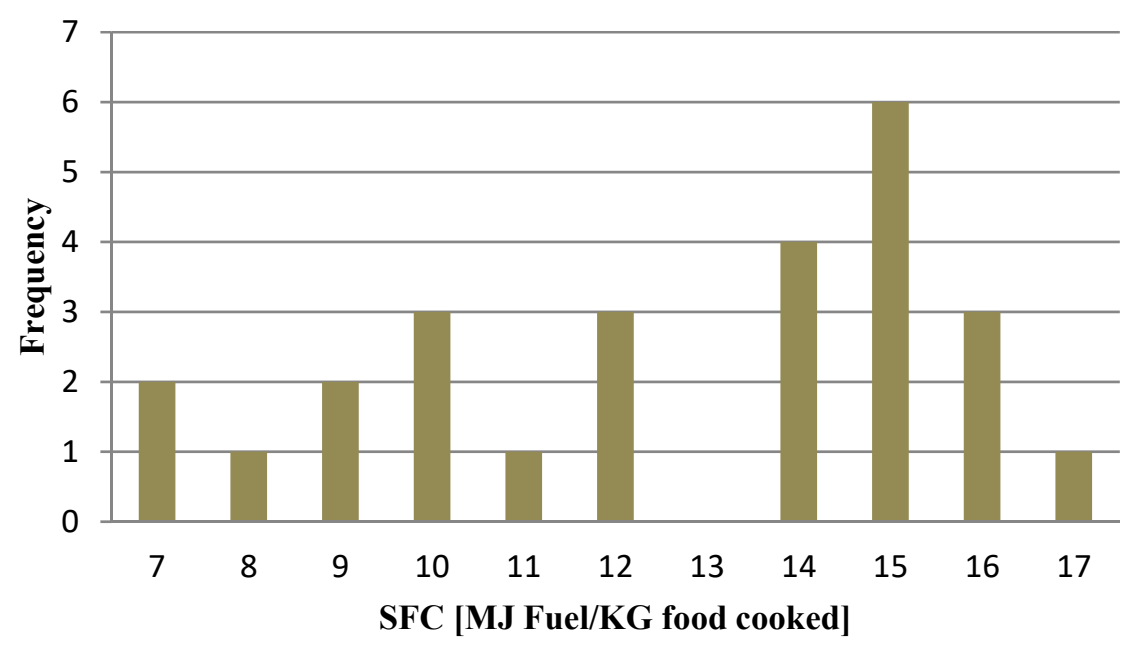

Figure 7: Frequency of Specific Fuel Consumption for the tested households.

\subsection{Aerosol measurement results}

The aerosol measurements were conducted in seven households (Fig. 8) over four days in parallel with the UCT. The measurements were tracked indoor PM2.5 smoke during cooking practices. The study does not report measurements of outdoor kitchens because the field survey reported the majority of household have indoor kitchens.

Results show that wood smoke from the 3-stone fire place had hourly average of $9800 \pm 3200 \mu \mathrm{g} / \mathrm{m}^{3}$. The reported concentration of smoke from the 3 -stone combustion process is presumed to be influenced by the constant adjustment of the wood (refuelling the fire by pushing wood) during the cooking process in order to maintain the heat. The process of disposing post-fire char results in the suspension, and increases ambient particulate loading.

\section{CONCLUSIONS AND RECOMMENDATIONS}

The results of this study indicate that a majority of Muculuone households rely on firewood as first choice fuel for cooking tasks and charcoal as the subsidiary alternative. The firewood is burnt in a 3-stone fire place and charcoal on a traditional metal stove. Among factors influencing their choice of energy technology are the food taste and the ease of use. These factors are linked to culture and socially constructed behaviours.

Each household consumes on average $204 \mathrm{MJ}$ of fuelwood energy per day when cooking for 4 to 6 hours, divided into morning, midday and evening sessions. The SFC (12 $\pm 3 \mathrm{MJ}$ fuel per $\mathrm{kg}$ food cooked) is independent of the number of pots used and the kind of meal cooked.

Smoke from wood-burning 3-stone fireplaces in indoor rural kitchens (total average concentration of $9800 \mu \mathrm{g} / \mathrm{m}^{3}$ ) is shown to be well above acceptable health standards (e.g. PM2.5 24-hour average $-64 \mu \mathrm{g} / \mathrm{m}^{3}$ US EPS standard [9]). However, the dense smoke plays an important role in food conservation, by fumigating and smoking grain, vegetables and meat. 


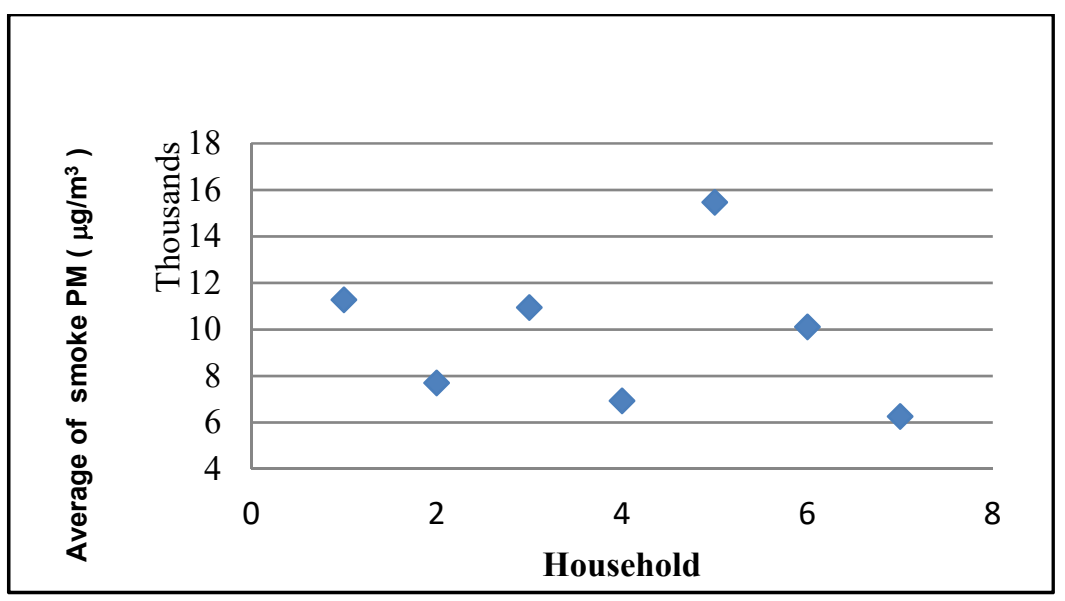

Figure 8: Hourly average PM2.5 concentrations from firewood smoke.

By using the methods stated above it is possible to establish a baseline of rural energy use and cooking system performance. Any proposed energy intervention in such communities should address the underlying cultural imperatives, the fuel options available and the preferred technologies.

\section{ACKNOWLEDGEMENTS}

Thanks are due to the SIDA/SAREC and the Energy Science and Technology Research Program project leader, G. Nhumaio.

This study formed part of the Volkswagen Foundation funded Biomodeling Project. The household questionnaire used in this study was developed jointly by the cohort of VW Doctoral Fellows: Charles Paradzayi, Alison, Mtumbi Goma, Alison Hughes and Momade Ibraimo. The contributions of these colleagues are gratefully acknowledged. Thanks are due to the VW Foundation and the project leaders: Ulrich Fahl, Ludger Eltrop, Timon Wehnert, Michael Knoll and Harold Annegarn.

We would like to acknowledge the assistance of Vincent Molapo (UJ SeTAR Centre) and Fabiano Simao (Eduardo Mondlane University) for their assistance with data gathering during the field trip, as well as the village elders who assisted with identifying and gaining consent from households. Assistance and funding was provided by Prof. H. Winkler (UJ) and Prof. M. Falcão (Eduardo Mondlane University) via the NRF (South Africa) and NRI (Mozambique) funded SAMOZ programme. We would also like to thank David Kimemia, Tafadzwa Makonese and Daniel Masekameni for their assistance.

\section{REFERENCES}

[1] Ibraimo, M., Annegarn, H., Winkler, H., Robinson, J. \& Molapo, T.V., Socio-economic aspects of domestic biomass use in Northern Mozambique. Paper presented at the People's Energy Network Conference, 20-21 October, Gaborone, Botswana, 2010.

[2] Pundo, M.O. \& Fraser, G.C.G., Multinominal logit analysis of household cooking fuel choice in rural Kenya: the case of Kisumu district. Agrekon, 45(1), 2006, http://ageconsearch.umn.edu/bitstream/31730/1/45010024.pdf 
[3] O’Sullivan, K. \& Barnes, D., Energy Policies and Multi-Topic Household SurveysGuidelines for Questionnaire Design in Living Standards Measurement, The World Bank: Washington, DC, 2006.

[4] Censo97, Estatisticas Sociais e Demograficos, Instituto Nacional de Estatistia, Mozambique, 2004.

[5] Mekonnen, A. \& Köhlin, G. Determinants of Household Fuel Choice in Major Cities in Ethiopia, Economics Work Group N39: University of Gothenburg, Sweden, 2009.

[6] AED, Fuel efficient stove programs in IDP settings - Summary evaluation report, Uganda, USAID, Washington, 2007.

[7] Bailis, R., Controlled Cooking Test (CCT Version 2.0), Shell Foundation, 2004, http://cleancookstoves.org/binary-data/DOCUMENT/file/000/000/80-1.pdf

[8] Robinson, J. \& Ibraimo, M., Pemberton-Pigott, The uncontrolled cooking test: measuring three-stone fire performance in northern Mozambique. Presented at the Domestic Use of Energy Conference, 12-13 April, Cape Peninsula University of Technology, Cape Town, 2011.

[9] Naeher, L.P., et al., Woodsmoke health effects: a review. Inhalation Toxicology, 19, pp. 67-106, 2007. 